\title{
Sialic acids as cellular markers of immunomodulatory action of dexamethasone on glioma cells of different immunogenicity
}

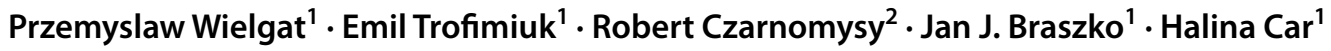

Received: 2 August 2018 / Accepted: 9 November 2018 / Published online: 15 November 2018

(c) The Author(s) 2018

\begin{abstract}
Glucocorticosteroids, including dexamethasone (Dex), are commonly used to control tumor-induced edema in the brain tumor patients. There are increasing evidences that immunosuppressive action of Dex interferes with immune surveillance resulting in lower patients overall survival; however, the mechanisms underlying these actions remain unclear. Changes in the expression of sialic acids are critical features of many cancers that reduce their immunogenicity and increase viability. Sialoglycans can be recognized by CD33-related Siglecs that negatively regulate the immune response and thereby impair immune surveillance. In this study, we analysed the effect of Dex on cell surface sialylation pattern and recognition of these structures by Siglec-F receptor in poorly immunogenic GL261 and immunogenic SMA560 glioma cells. Relative amount of $\alpha 2.3-, \alpha 2.6$ - and $\alpha 2.8$-linked sialic acids were detected by Western blot with MAA (Maackia amurensis) and SNA (Sambucus nigra) lectins, and flow cytometry using monoclonal antibody anti-PSA-NCAM. In response to Dex, $\alpha 2.8$ sialylation in both, GL261 and SMA560 was increased, whereas the level of $\alpha 2.3$-linked sialic acids remained unchanged. Moreover, we found the opposite effects of Dex on $\alpha 2.6$ sialylation in poorly immunogenic and immunogenic glioma cells. Furthermore, changes in sialylation pattern were accompanied by dose-dependent effects of Dex on Siglec-F binding to glioma cell membranes as well as decreased $\alpha$-neuraminidase activity. These results suggest that glucocorticosteroid-induced alterations in cell surface sialylation and Siglecs recognition may dampen anti-tumor immunity, and participate in glioma-promoting process by immune cells. Our study gives new view on corticosteroid therapy in glioma patients.
\end{abstract}

Keywords Glioma $\cdot$ GL261 $\cdot$ SMA560 $\cdot$ Dexamethasone $\cdot$ Sialic acid $\cdot$ Siglec $\cdot$ Immunogenicity

\section{Introduction}

Gliomas are the most common primary brain tumors characterized by high pharmacological resistance and poor prognosis $[1,2]$. The aggressive potential of glial tumors is attributed to altered expression of genes that control cell signaling, cytoskeletal and receptor proteins as well as cell migration [3-6]. Analysis of gene profiles confirmed also down regulation of MHC I/II proteins expression and increased production of glioma-derived immunosuppressive factors which reverse immune response mechanisms

Przemyslaw Wielgat

przemyslaw.wielgat@umb.edu.pl

1 Department of Clinical Pharmacology, Medical University of Bialystok, Waszyngtona 15A, 15-274 Bialystok, Poland

2 Department of Synthesis and Technology of Drugs, Medical University of Bialystok, Kilińskiego 1, 15-089 Bialystok, Poland
$[7,8]$. There are increasing evidences that weak immune surveillance of various cancers, including gliomas, correlates with altered sialylation in malignant cells [9-12]. Sialic acids are nine carbon monosaccharides that occupy terminal positions on glycans through $\alpha 2.3-, \alpha 2.6$ - and $\alpha 2.8$ linkage, regulate glycoconjugates structure and stability as well as participate in cell-cell and cell-extracellular matrix interactions, including immune recognition [13]. The aberrantly expressed sialic acids reduce cancer immunogenicity by masking of cell surface antigens, recruiting of plasma factor $\mathrm{H}$ to control of alternative complement pathways and protecting from clearance by liver receptors [14]. The tumor immune evasion is also facilitated by immune receptor families, such as Siglecs, that recognize cancer sialoglycans and transmit immunosuppressive signals resulting in negative regulation of immune response $[13,15]$. The altered sialylation status in malignant cells results from genetic mutations in enzymes that control processing and degradation of bound sialic acids in glycoproteins and glycolipids [16-18]. 
Additionally, numerous chemical and physical factors are known as modulators of sialotransferases and sialidases activities resulting in hyposialylation or hypersialylation of cellular membranes [19-21].

Dexamethasone (Dex) is a potent steroid commonly used to control tumor-linked edema and radio- and chemotherapyinduced side effects in brain cancer patients [22]. Although Dex is considered as the "gold standard" in glioma therapy for decades, there are growing evidences that effects of corticosteroids on glioma cell growth and patient survival are controversial [23]. The data from mouse glioma models and retrospective clinical analysis showed that Dex may decrease tumor cell proliferation without affecting glioma cell viability and induce gene expression correlated with shorter survival [24]. Both preclinical and clinical observation revealed that Dex may interfere with function of local immune cells resulting in potentiation of glioma-induced weak immunosurveillance. The immunosuppressive actions of corticosteroids can be exerted by nongenomic mechanisms related to interaction with intracellular proteins and modulation of cell membrane adhesion proteins and antigens implicated in the immune recognition [25]. Based on these observations, we evaluated the effect of Dex on sialylated $\mathrm{N}$-glycans and $O$-glycans profiles and their recognition by Siglec-F immune receptor. Using glioma cell lines of different histological origin and immunogenicity, we present evidences that Dex-induced changes in cell surface sialylation may interfere with immunogenic potential of glioma cells. Our results emphasize the role of sialic acids in tumor biology and identify Siglec-F as potential important player in glioma immune surveillance during Dex therapy.

\section{Materials and methods}

\section{Cell cultures and treatment}

Both, GL261 (ACC802, DSMZ Germany) and SMA560 (provided by Prof. Neumann, University of Bonn) cells were plated in 6 well plates at a seedinig density $2 \times 10^{5} / 9 \mathrm{~cm}^{2}$, cultured in DMEM/F12 medium containing $10 \%$ fetal bovine serum and $1 \%$ antibiotics, and incubated in $37^{\circ} \mathrm{C}$ in a humified atmosphere containing $5 \% \mathrm{CO}_{2}$. When cells reached confluence at 70-80\%, Dex (Dexaven, Jelfa Poland; $0.1 \mu \mathrm{M}$, $1 \mu \mathrm{M}, 10 \mu \mathrm{M}$ ) was applied to cell cultures for $24 \mathrm{~h}$. Concentrations of Dex was selected based on previous studies [26].

\section{Cell cycle}

After $24 \mathrm{~h}$ of Dex treatment, cells were carefully harvested by scraping, fixed in ice-cold $70 \%$ methanol, treated with ribonuclease and stained with propidium iodide (PI, $50 \mu \mathrm{g} / \mathrm{ml}$ ) for DNA quantification. The distribution of PI fluorescence in cells was quantified using flow cytometry by their distribution in $\mathrm{G} 0 / \mathrm{G} 1, \mathrm{~S}$ and $\mathrm{G} 2 / \mathrm{M}$ phases. The $\mathrm{S}+\mathrm{G} 2 / \mathrm{M}$ population was quantified as proliferating cells.

\section{Determination of Olig2 expression in GL261 and SMA560 cells}

The Olig2 protein is transcription factor known to be required for proliferation of glial tumors and regulated by several sialoglycan expression [27, 28]. Naïve and Dextreated cells were scraped, diluted to $10^{5}$ per sample and incubated with Olig2 (Abcam, 2,5 $\mu \mathrm{g} / \mathrm{ml}$ ) antibody for $30 \mathrm{~min}$ at $4{ }^{\circ} \mathrm{C}$. To facilitate intracellular staining, $0.01 \%$ Triton was used. Cells were washed with phosphate buffered saline, stained with appropriate secondary fluorescent antibody and analysed on Becton Dickinson flow cytometry system. In each analysis, corresponding isotype control antibody was used as a negative control.

\section{Assessment of a2,3- and a2,6- and a2,8-sialylation in glioma cells}

The $\alpha 2,3$ - and $\alpha 2,6$-linked sialic acids in GL261 and SMA560 cells were analysed using the DIG Glycan Differentiation Kit (Roche, Germany) following the manufacturer's instructions. Terminal sugar structures were recognized by Maackia amurensis agglutinin (MAA) and Sambucus nigra agglutinin (SNA), that bind $\alpha 2,3-$ and $\alpha 2,6$-linked sialic acids, respectively. For Western blot, naïve and Dextreated cells were homogenized in RIPA buffer containing proteases inhibitors. Twenty micrograms $(20 \mu \mathrm{g})$ of protein from cellular homogenates were loaded into 10\% SDS-polyacrylamide gel, electrophoresed and transferred to PVDF membrane. Blots were incubated with digoxygenin-labeled lectins at $4{ }^{\circ} \mathrm{C}$ overnight and anti-digoxygenin Fab fragments conjugated with alkaline phosphatase for $1 \mathrm{~h}$ at room temperature. Immunoreactive sialoglycoproteins were visualized with BCIP/NBT Liquid Substrate System (Sigma Aldrich) for alkaline phosphatase. Membranes were scanned and analysed densitometrically using Quantity One (Bio-rad Laboratories, Inc.) and ImageJ softwere. Protein concentration in each sample was estimated by the method of Bradford using bovine serum albumin as a standard [29]. To estimate the level of $\alpha 2.8$-sialylation, cells were analysed by flow cytometry after incubation with primary PSA-NCAM antibody (Merck, $2 \mu \mathrm{g} / \mathrm{ml}$ ) for $30 \mathrm{~min}$ at $4{ }^{\circ} \mathrm{C}$ and staining with appropriate secondary, isotype specific FITC-conjugated antibody (Abcam, $2 \mu \mathrm{g} / \mathrm{ml}$ ). In each analysis, corresponding isotype control antibody was used. The amount of PSA-NCAM was determined according to isotype control antibodies used as negative control (Abcam, $2 \mu \mathrm{g} / \mathrm{ml}$ ). 


\section{Determination of Siglec-F binding to glioma cells}

To assess the binding of Siglec-F protein to glioma cells, the control and Dex-treated cells were incubated with recombinant mouse Siglec-F/Fc Chimera (R\&D Systems, $1 \mu \mathrm{g} / \mathrm{ml}$ ) and then stained with $\mathrm{Cy} 3$ conjugated IgG secondary antibody (Jackson ImmunoResearch, $2 \mu \mathrm{g} / \mathrm{ml}$ ). Samples were analysed by flow cytometry and cells stained using the secondary antibody alone were used as negative control. Sialic acid-dependent binding of Siglec-F was confirmed using $\alpha$-neuraminidase. Briefly, the growing cells were incubated with $\alpha$-neuraminidase $(100 \mathrm{U} / \mathrm{ml}$, from Clostridium perfringens, New England Biolabs) for $24 \mathrm{~h}$ at $37^{\circ} \mathrm{C}$.

\section{a-Neuraminidase activity assay}

The total Neu activity was assayed using Amplex Red Neuraminidase Assay Kit (Invitrogen) following manufacturer's instruction. In brief, $50 \mu \mathrm{l}$ of diluted cell homogenate containing equal protein amount $(30 \mu \mathrm{g})$ was incubated with $50 \mu \mathrm{l}$ of Amplex Red working solution comprising $100 \mu \mathrm{M}$ Amplex Red reagent; $0.2 \mathrm{U} / \mathrm{ml}$ horseradish peroxidase; $4 \mathrm{U} /$ $\mathrm{ml}$ galactose oxidase and $500 \mu \mathrm{g} / \mathrm{ml}$ fetuin. The activity was measured as absorbance and read at $560 \mathrm{~nm}$ using BioTek EL800 microtiter plate reader.

\section{Statistical analysis}

For each group, a minimum of 3-5 independent experiments were studied. The statistical analysis was performed using one way ANOVA followed by Bonferroni post-test. Results are expressed as mean \pm SD. Significant differences were deemed at $p<0.05$.

\section{Results}

\section{Dexamethasone treatment effects on glioma GL261 and SMA560 cells growth}

The exposure to Dex for $24 \mathrm{~h}$ induced changes in the distribution of glioma cells along the $\mathrm{G}_{\mathrm{o}} / \mathrm{G}_{1}$ and $\mathrm{S}+\mathrm{G}_{2} / \mathrm{M}$ cycle phases, but these effects were relatively weak. In GL261 cells, the increasing concentrations of Dex caused enhancement in the number of cells within the $\mathrm{G}_{\mathrm{o}} / \mathrm{G}_{1}$ phase, from $52 \%$ of the naïve cell population to $61.6 \%$ of cells treated with $10 \mu \mathrm{M}$ Dex. The percentage of proliferating cells within $\mathrm{S}+\mathrm{G}_{2} / \mathrm{M}$ phase was correspondingly decreased from $41.3 \%$ of the untreated GL261 cells to $33.9 \%$ cells exposed to the higher concentration of Dex (Fig. 1a, c). In SMA560 cells, exposure to Dex for $24 \mathrm{~h}$ caused enhancement in the number of cells displaying $\mathrm{G}_{0} / \mathrm{G}_{1}$ phase and correspond decrease of percentage of the population within $\mathrm{S}+\mathrm{G}_{2} / \mathrm{M}$ phase, but these effects were weak when compared to untreated cells (by 6\%; Fig. 1b, c).

\section{Effects of dexamethasone on Olig2 expression in GL261 and SMA560 cells}

In additional quantification of anti-proliferatory Dex effects, we analysed the expression of Olig2 known as a transcriptional regulator of proliferation and glioma tumorigenesis. Both, control proliferating GL261 and SMA560 cells expressed high level of Olig2. In GL261 cells, the Olig2 expression was significantly decreased at Dex concentration of $1 \mu \mathrm{M}$ and $10 \mu \mathrm{M}$, but not $0.1 \mu \mathrm{M}$, after $24 \mathrm{~h}$ of treatment compared to control $(0.1 \mu \mathrm{M}$ Dex: $95.4 \pm 3.3 \%$ vs. $100 \%$ control; $1 \mu \mathrm{M}$ Dex: $80.6 \pm 8 \%$ vs. $100 \%$ control; $10 \mu \mathrm{M}$ Dex: $74 \pm 11,8 \%$ vs. $100 \%$ control). In SMA560 cells, the treatment with increasing concentrations of Dex, resulted in slight decrease of Olig2 expression (0.1 $\mu \mathrm{M}$ Dex: $96 \pm 3.2 \%$ vs. $100 \%$ control; $1 \mu \mathrm{M}$ Dex: $91.8 \pm 6.5 \%$ vs. $100 \%$ control; $10 \mu \mathrm{M}$ Dex: $92 \pm 5.8 \%$ vs. $100 \%$ control; Fig. 2 ).

\section{Effects of dexamethasone treatment on sialylation of glioma cells}

To visualize $\alpha 2.3$ - and $\alpha 2.6$-sialylation pattern, the proteins from cellular homogenates were separated on SDS-PAGE, electroblotted and labelled with appropriate lectins. Representative blots and corresponding density bars presented in the Fig. 3 illustrate the amount of terminal linkage-specific sialic acids on cell surface glycoconjugates. In response to increasing concentrations of Dex, $\alpha 2.3$-sialylation determined by the level of reactivity for MAA lectin was remained unchanged in both GL261 and SMA560 cells compared to naïve cells (Fig. 3A, C). The not significantly higher reactivity of MAA lectin with $\alpha 2.3$-linked sialic acids in GL261 and SMA560 cells was observed in molecular weight around $49 \mathrm{kDa}$ at all tested concentrations of Dex (Fig. 3a, c). The $\alpha 2.6$-sialylation in SMA560 cells was decreased across the full molecular weight range as compared to naïve population (Fig. 3d). In contrast with SMA560 cells, the reactivity of SNA lectin in GL261 cells was differentially regulated by increasing concentrations of Dex. The densitometric measurement of selected lanes showed reduced $\alpha 2.6$ sialylation of glycoconjugates in the molecular weight above $49 \mathrm{kDa}$, but strongly enhanced under $49 \mathrm{kDa}$ (Fig. 3b). The level of $\alpha 2.8$-sialylation was assessed by flow cytometric measurement of polysialic acid posttranslationally attached to NCAM (PSA-NCAM). The effects of increasing concentrations of Dex on PSA-NCAM expression in SMA560 cells were opposite to those seen in $\alpha 2.6$-sialilation of these cells. After $24 \mathrm{~h}$ of treatment with Dex, PSA-NCAM expression in SMA560 cells were significantly enhanced to: $0.1 \mu \mathrm{M}$ : $132.2 \pm 15.2 \%$ vs. control $(100 \%) ; 1 \mu \mathrm{M}: 138 \pm 12.1 \%$ versus 

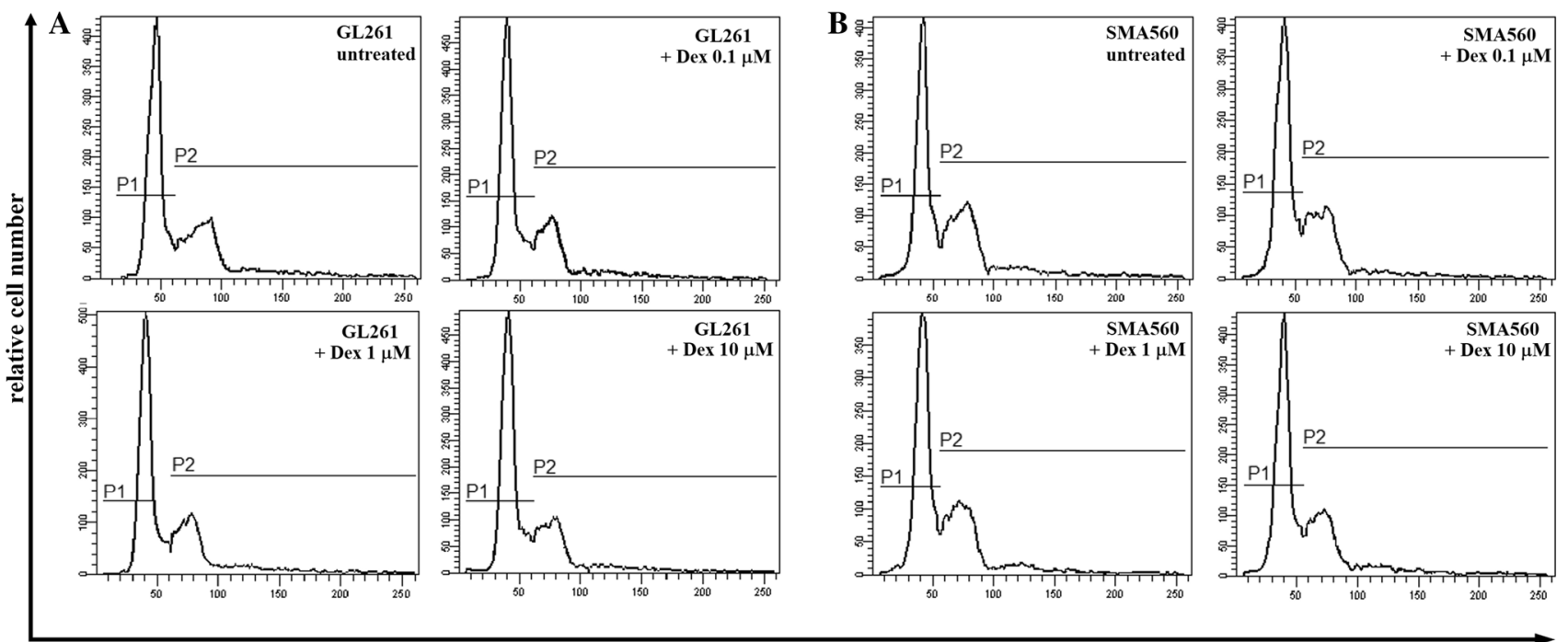

PI fluorescence (relative units)

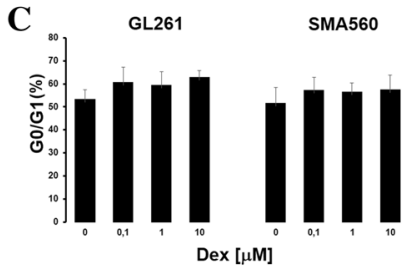

Fig. 1 Dose-dependent effects of Dex on the cell cycle phase distribution of GL261 (a) and SMA560 (b) cells. Representative histograms and corresponding bar graphs (c) were derived from 10,000 cells and present the percentage of population within the $G_{0} / G_{1}(P 1)$ and $\mathrm{S}+\mathrm{G}_{2} / \mathrm{M}(\mathrm{P} 2)$ phases of cell cycle. Each data point is a mean of 3 independent experiments
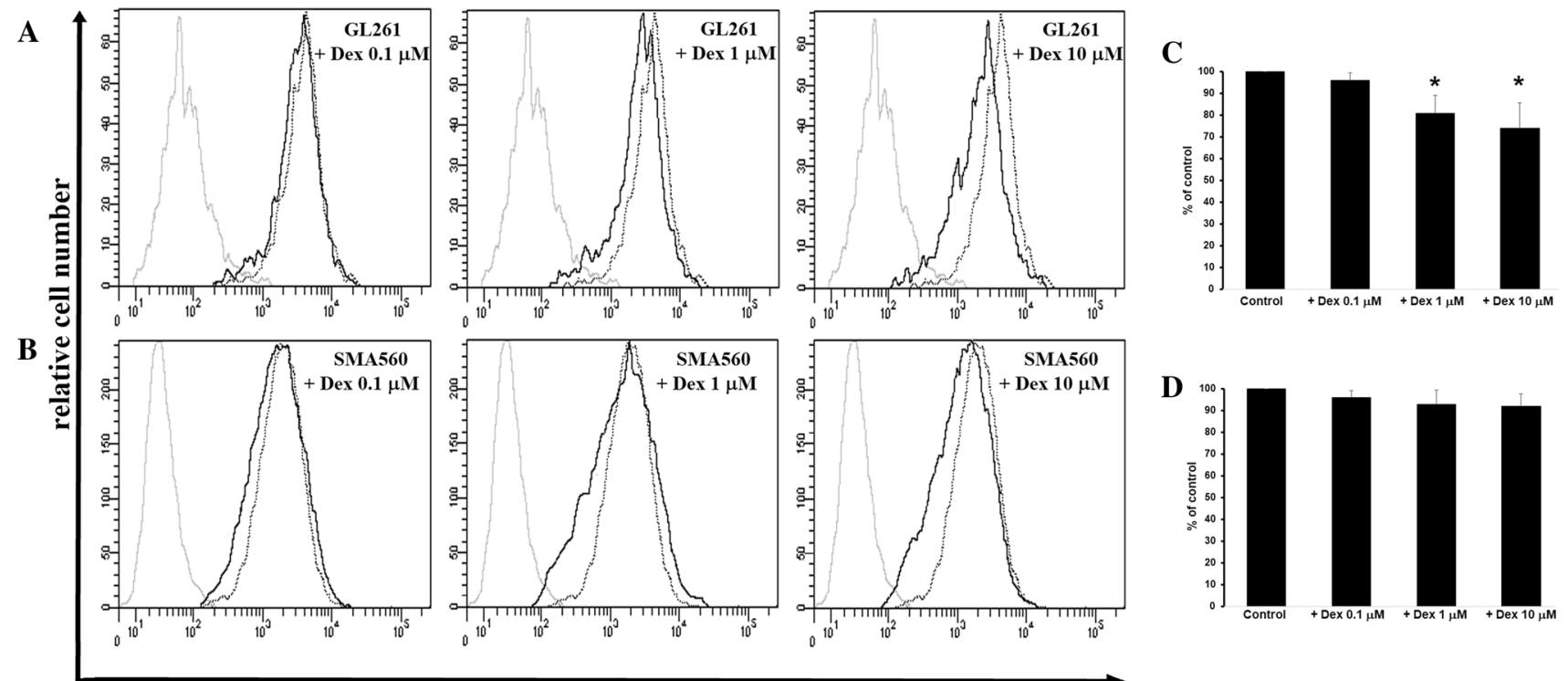

FITC fluorescence (relative units)

Fig. 2 Expression of Olig2 in GL261 (a) and SMA560 (b) cells exposed to Dex. Representative histograms were derived from analysis of 10,000 cells and show isotype control (light grey line); control cells (dropped line) and cells treated with Dex (black line). c, d each column presents mean \pm SD of 3-5 independent experiments. Data are presented as a percentage of control group $(100 \%) ;{ }^{*} p<0.05$ versus control 

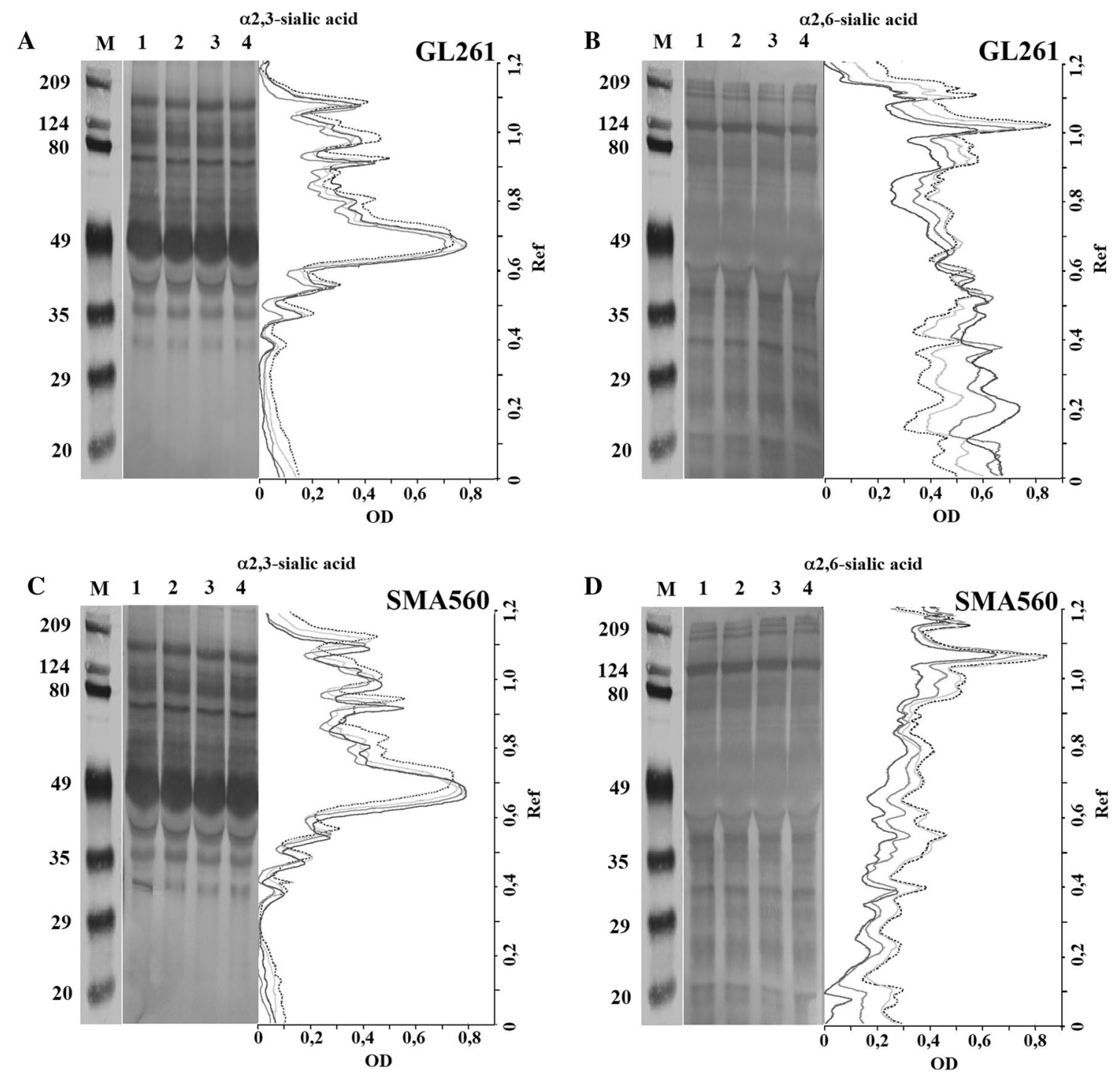

Fig. 3 Sialoglycans in GL261 and SMA560 cells exposed to Dex. Representative Western blots of $\mathbf{a} \alpha 2,3-$ and $\mathbf{b} \alpha 2,6$-sialylated glycoconjugates and corresponding density histograms are shown (dropped

line—control cells; light grey line-Dex $0.1 \mu \mathrm{M}$; grey line-Dex $1 \mu \mathrm{M}$; black line-Dex $10 \mu \mathrm{M}$ ). Lanes show: $M$ molecular weight standards, 1 control cells, 2 Dex $0.1 \mu \mathrm{M}, 3$ Dex $1 \mu \mathrm{M}, 4$ Dex $10 \mu \mathrm{M}$

control (100\%); $10 \mu \mathrm{M}: 136.3 \pm 23.6 \%$ versus control (100\%; Fig. 4b, d). The treatment of GL261 cells with increasing concentrations of Dex for $24 \mathrm{~h}$ caused statistically insignificant increase in PSA-NCAM expression as follows: $0.1 \mu \mathrm{M}$ : $122.7 \pm 7.9 \%$ versus control (100\%); $1 \mu \mathrm{M}: 124 \pm 3.2 \%$ versus control (100\%); $10 \mu \mathrm{M}: 113.3 \pm 9.2 \%$ vs. control (100\%; Fig. 4a, c).

\section{The binding capacity of Siglec-F/Fc Chimera to glioma cells}

The analysis of Siglec-F/Fc Chimera positive cells, expressed as a mean relative fluorescence intensity, evidenced differences between control and Dex-treated groups.

The measurement of the effect of $\alpha$-neuraminidase, used here as a positive control, showed signifficant reduction of Siglec-F/Fc Chimera binding to GL261 and SMA560 cells by $42 \pm 9.7 \%$ vs. control $(100 \%)$ and $40 \pm 10.9 \%$ vs. control (100\%), respectively (Fig. 5c, f). Dex at all used concentrations reduced the binding capacity of Siglec-F/Fc protein to both GL261 and SMA560 cells. In details, the mean fluorescence intensity of SMA560 cells was significantly decreased at Dex concentration of $0.1 \mu \mathrm{M}$ and $1 \mu \mathrm{M}$ but $10 \mu \mathrm{M}$, after $24 \mathrm{~h}$ of treatment compared to control $(0.1 \mu \mathrm{M}$ Dex: $62 \pm 21.5 \%$ vs. $100 \%$ control; $1 \mu \mathrm{M}$ Dex: $68 \pm 20.8 \%$ vs. $100 \%$ control; $10 \mu \mathrm{M}$ Dex: $84 \pm 8.8 \%$ vs. $100 \%$ control; Fig. 5b, e). When GL261 cells were exposed to Dex, the affinity of Siglec-F/Fc protein tended to be reduced, but 
A

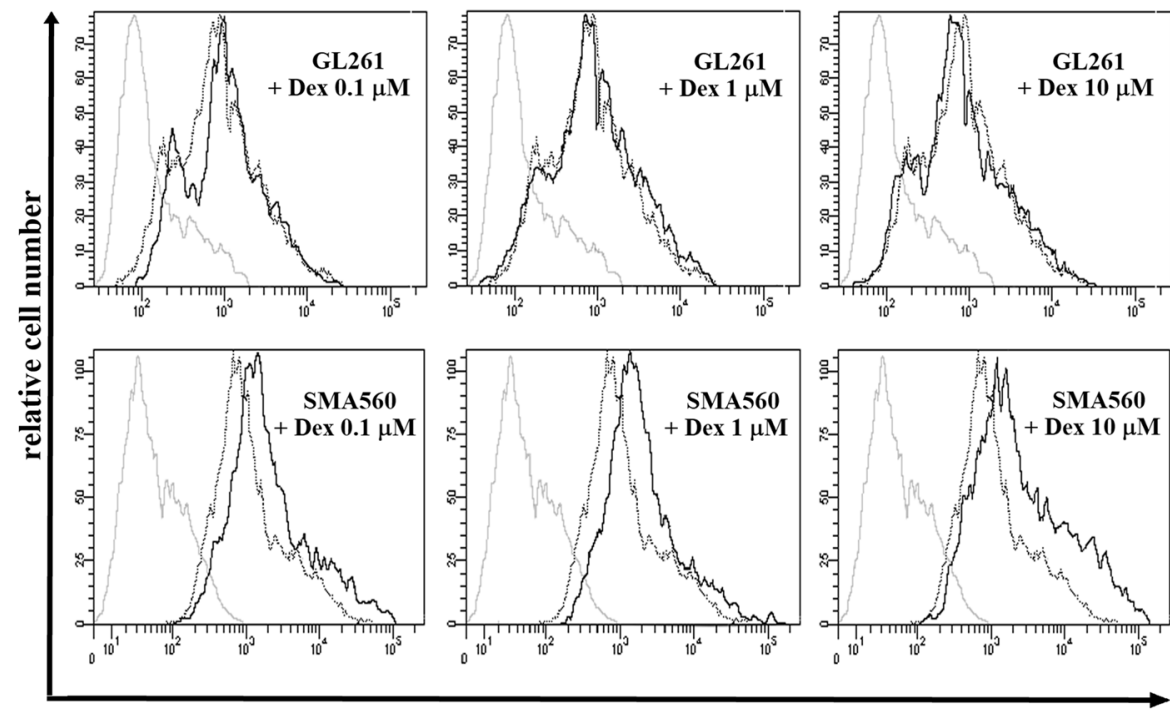

C

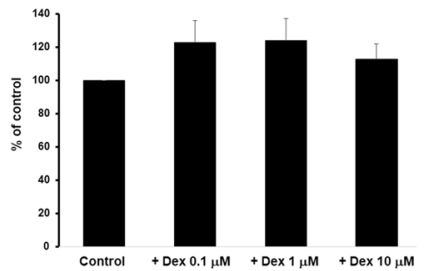

D

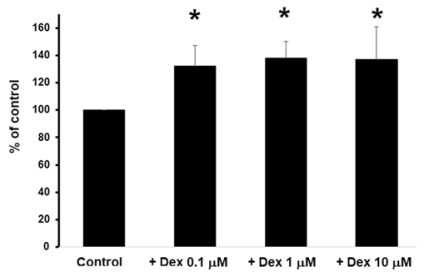

Fig. 4 Flow cytometric analysis of PSA-NCAM containing $\alpha 2,8$ linked sialic acids in GL261 and SMA560 cells after exposure to Dex. Representative histograms $(\mathbf{a}, \mathbf{b})$ were derived from analysis of 10,000 cells and show isotype control (light grey line); control cells

differences were not significant at concentration of 1 and $10 \mu \mathrm{M}(0.1 \mu \mathrm{M}$ Dex: $78 \pm 10.7 \%$ vs. $100 \%$ control, $p<0.05$; $1 \mu \mathrm{M}$ Dex: $90 \pm 9.5 \%$ vs. $100 \%$ control; $10 \mu \mathrm{M}$ Dex: $85 \pm 12.7 \%$ vs. $100 \%$ control); Fig. 5 a, d.

\section{Effects of dexamethasone on a-neuraminidase activity}

To confirm that Dex exerts dose-dependent changes in glioma cell sialylation, we assessed the activity of $\alpha$-neuraminidase which is closely associated with sialoglycans turnover. Our experiment with the treatment of GL261 and SMA560 cells with increasing concentrations of Dex for $24 \mathrm{~h}$ showed that $\alpha$-neuraminidase enzymatic activity was decreased in both cell lines (Fig. 6). In GL261 cells, enzymatic activity decreased by $15 \%, 13 \%$ and $8 \%$ at Dex concentration of $0.1 \mu \mathrm{M} ; 1 \mu \mathrm{M}$ and $10 \mu \mathrm{M}$, correspondingly, compared to control group. The neuraminidase activity decreased significantly in SMA560 cells by $31 \%(p<0.05)$, $33 \%(p<0.05)$ and not significantly by $19 \%$ at Dex concentration of $0.1 \mu \mathrm{M} ; 1 \mu \mathrm{M}$ and $10 \mu \mathrm{M}$, respectively .

\section{Discussion}

As mentioned in the introduction, several studies closely connect the aberrant sialylation to tumor immune evasion. Corticosteroids, since they are known as potent modulators of cell biology, stimulate malignant cells and cancer-related (dropped line) and cells exposed to Dex (black line). c, d each column presents mean \pm SD of 3-5 independent experiments. Data are presented as a percentage of control group (100\%); ${ }^{*} p<0.05$ versus control

immune processes have been investigated in several clinical studies and experimental models. In this work, we hypothesized that Dex involvement in immune surveillance is regulated by mechanisms linked to changed sialic acids and their recognition by Siglecs. We used glioma cells of different immunogenicity, as determined in independent studies based on expression of MHC proteins and immune activity in vivo and in vitro [7]. The GL261 cells are poorly immunogenic due to low expression of MHC Class I/II molecules. In contrast, the SMA560 cells present MHC Class I, which enhances their recognition by effector immune cells [30-32]. Comparison of sialylation pattern in analysed naïve glioma cells indicated that the level of $\alpha 2.3$ - and $\alpha 2.8$-sialylation was similar in both naïve GL261 and SMA560 cells, whereas $\alpha 2.6$-sialylation was higher in GL261 cells. This is perhaps because the glioma cell lines may be significantly different in their expression and activity of regulatory mechanisms of cell surface sialylation, and adhesion molecules that promote their malignant phenotypes. Secondly, elevated degree of sialylation in GL261 cells may reflect reduced immunogenicity as described previously in various pathologies [14]. The aberrant $\alpha 2.6$-sialylation correlates with tumorigenesis and tumor progression, and the elevated presence of $\alpha 2.3$ sialic acid residues constitutes a typical feature of tumor adhesion and invasion [33-35]. The exposure of glioma cells to Dex exerted dose-dependent changes in $\alpha 2.3$-; $\alpha 2.6$ - and $\alpha 2.8$-sialoglycotopes. Our results indicated that the degree of a2.8-sialylation was elevated in poorly immunogenic cells, and strongly increased in immunogenic glioma cell line. In 


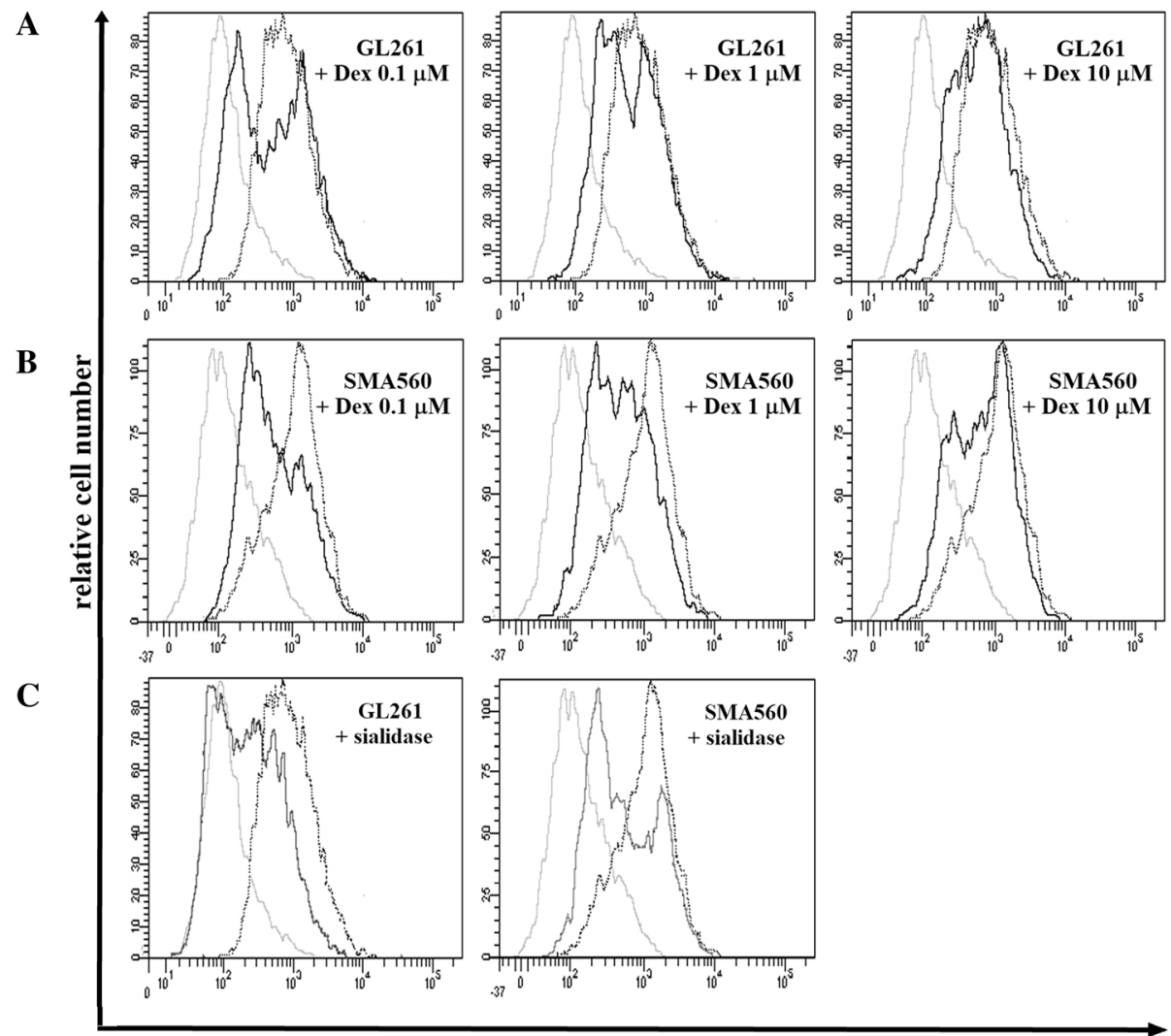

D

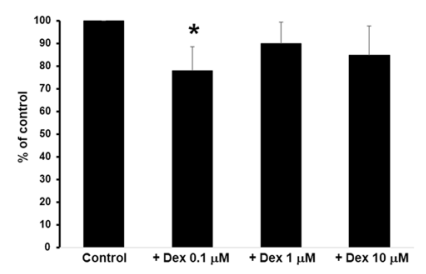

$\mathbf{E}$

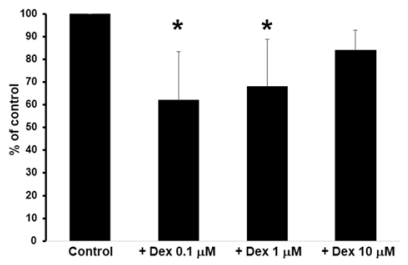

F

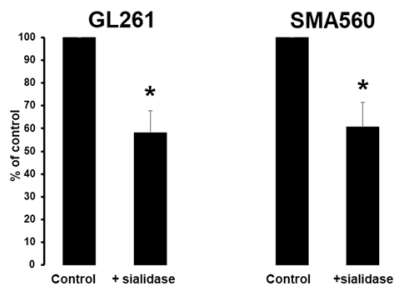

FITC fluorescence (relative units)

Fig. 5 The binding of Siglec-F/Fc Chimera to GL261 (a) and SMA560 (b) glioma cells. Representative histograms were obtained from flow cytometric analysis of 10,000 cells and show isotype control (light grey line); control cells (dropped line) and cells exposed to Dex (black line). d, e each column presents mean \pm SD of 3-5 inde-

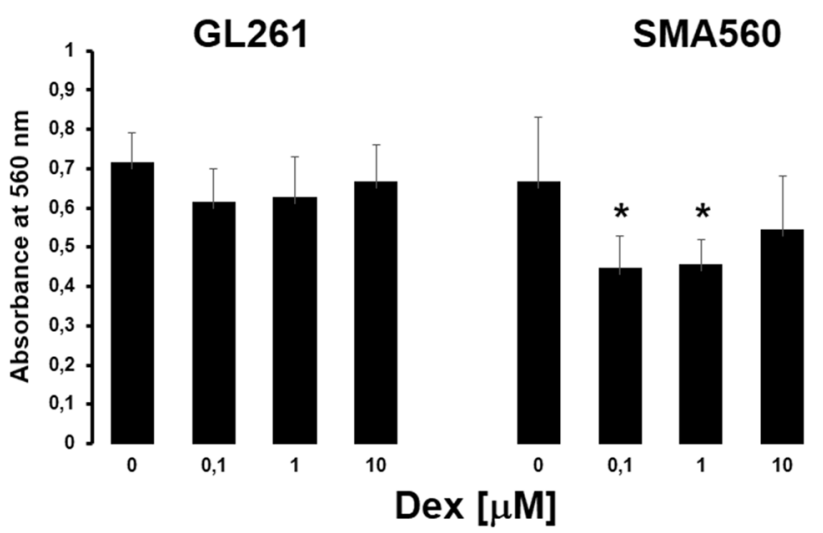

Fig. 6 Detection of neuraminidase activity using the Amplex Red Neuraminidase Assay Kit in GL261 and SMA560 cells treated with Dex. Absorbance at $560 \mathrm{~nm}$ is shown. Each column presents mean \pm SD of 3 independent experiments; $* p<0.05$ versus control pendent experiments. The histograms (c) and appropriate bar graphs (f) showing cells treated with $\alpha$-neuraminidase used here as positive control are also included (light grey line); control cells (dropped line) and $\alpha$-neuraminidase treated cells (black line). Data are presented as a percentage of control group (100\%); ${ }^{*} p<0.05$ versus control

the same experimental conditions, the expression of $\alpha 2.3-$ Sia glycotopes among selected stimulated cells remained unchanged or increased compared to naïve cells, but these effects were relatively weak. Interestingly, the expression of $\alpha 2.6-S i a$ residues was higher in poorly immunogenic cells and reduced in immunogenic cell line. In malignant cells, the sialylation is altered by sialyltransferases and sialidases dysregulation, which is distinctive feature of each cancer. It is conceivable, that elevated level of $\alpha 2.6-S i a$ glycotopes in GL261 cells results from aberrant expression and activity of $\alpha 2.6$-sialyltransefase ( $\alpha 2.6$-ST), which regulates malignant phenotype of these cells. Several studies have demonstrated that expression and activity of $\alpha 2.6-\mathrm{ST}$ was induced after concentration dependent corticosteroid stimulation in a number of different tissues, including cancerous [36, 37]. In this study, subsequent examination of individual sialylation regulatory enzymes demonstrated strong decrease of total sialidase activity following dexamethasone exposure in SMA560 cells but not in GL261. Since we showed participation of lysosomal glycosidases in human gliomas progression and 
modulatory effects of corticosterone on sialidases activity in rodent brain, it is reasonable to suggest their crucial role in glioma biology, including immunogenicity. The Dexinduced changes in cell membrane sialylation can be related to differences in glycoproteins structure during cell cycle. Our results suggest that Dex inhibited proliferation of both GL261 and SMA560 by $\mathrm{G}_{0} / \mathrm{G}_{1}$ phase arrest in cell cycle. Moreover, the most effective Dex concentration decreasing Olig2 expression - $10 \mu \mathrm{M}$-corresponded to that revealed as the most arresting $\mathrm{G}_{0} / \mathrm{G}_{1}$ phase in GL261 and SMA560 cells. It has been shown previously that the total content of several monosaccharides is at minimum, whereas the degree of sialylation is at maximum just before and during cell division glycotopes [38]. It is in agreement with our observation that reduced sialylation correspond to Dex-induced growth inhibition in immunogenic SMA560 cells. In contrast, partially immunogenic GL261 cells showed cell cycle arrest in G0/G1 phase after exposure to Dex and increased level of $\alpha 2.6-$ Sia. Similar changes were described by Glick et al. in slow growing cells extendend in G1 phase [39]. Since selected cell lines were tested in the same experimental conditions, the differences in sialylation degree were probably due to their phenotype, which can be evaluated by expression and distribution glioma of proliferation and tumorigenesis markers.

The ability of cancer to induce the host anti-tumor immune response depends on defence mechanisms in resident and infiltrating immune cells that are activated by tumoral soluble factors or during cellular interactions [40-42]. Sialic acids in tumor cells form ligands for CD33related Siglecs which trigger suppressive signalling to immune cells via tyrosine-based inhibitory motifs (ITIM) and SHP1/SHP2 molecules that modulate cytotoxic and inflammatory responses leading to increased pathology development [43, 44]. Siglec-F, inhibitory CD33-related sialic acid receptor, is highly expressed on murine eosinophils, macrophages and CD4-positive $\mathrm{T}$ cells, which are a part of complex glioma microenvironment [45, 46].

As we showed in this study, the naïve glioma cells express high level of sialic acids. They cover tumoral antigens and exert masking effects that facilitate escape from recognition by immune cells [11]. In multivariate analyses, enhanced level of polysialylated NCAMs (PSA-NCAMs) was an independent negative predictor of overall survival of patients with GBM [27]. Besides, sialylated glycans form ligands for CD33-related Siglecs which activate the cellular signalling pathways via tyrosine-based inhibitory motifs (ITIM) and SHP1/SHP2 molecules resulting in cellular inhibition [47]. In this study, sialoglycans of GL261 and SMA560 cells showed high reactivity with recombinant Siglec-F protein. Furthermore, the binding of recombinant Siglec-F protein to glioma cells was strongly reduced by the lowest concentration of Dex, whereas the highest dose had a minimal effect on this process. The effects produced by various doses of Dex were more intense in immunogenic compared to poorly immunogenic glioma cells. This finding may reflect high expression of $6^{\prime}$-sulfated sialyl Lewis X (6'-su-sLeX), which was described as endogenous and inducible ligand for Siglec-F [48-50]. The expression of 6'-su-sLeX and sulfotransferase keratin sulfate galactose 6- $O$-sulfotransferase (KSGal6ST), an enzyme required for its synthesis, were detected in various cancers, including gliomas, and is routinely used as a marker for diagnosis, grading and prognosis [51, 52]. The crosstalk between glioma and immune cells via sialic acid-Siglec-F connection support tumor-promoting functions, including angiogenesis, proliferation, remodeling of extracellular matrix and recruitment of immunosuppressive myeloid cells [53]. Engblom et al. showed that presence of Siglec-F-positive neutrophilia within tumor promotes cancer growth and correlates with poor prognosis [54]. In contrary, eosinophilia in GBM patients correlates with longer survival but Siglec-F-dependent apoptosis of eosinophils appears to be negative prognostic factor [45]. Furthermore, human Siglec-7 on NK cells shows strong binding prevalence for $\alpha 2.8$-linked sialic acids, and thereby leads to an inhibition of these cells cytotoxicity. In this way, Siglec-7 can potentially dampen anti-tumor immunity and promote cancer invasion [55]. Additionally, it has been demonstrated previously, that glucocorticosteroids increase expression of several Siglecs in immune cells in vivo [56, 57]. Given the importance of sialylation and Siglecs in immunity it is reasonable to speculate that Dex can be crucial factor regulating immunogenic potential of gliomas and immunosuppressive phenotype and survival of tumor-associated immune cells. It is in line to several clinical trial observations that higher doses of steroids were negative prognostic factor in patients with large glial tumors and more prominent neurological deficits [24, 58]. The explanation of modulatory role of Dex in sialic acid-dependent immunogenicity requires the analysis of human cell populations implicated in glioma progression. The comparison of sialylation pattern and Siglec-related changes in gliomas and tumor-associated cells could help to evaluate the immune surveillance during Dex therapy and develop new strategies based on changes of Siglecs function and their sialylated ligands.

In conclusion, this study showed that Dex alter both GL261 and SMA560 sialoglycans, but the corresponding differences between their sialylation pattern suggest that these steroid-induced changes in glioma cells of different immunogenicity are not identical. The relationship between changes in sialic acids and their recognition by Siglecs as well as widely known effects of steroids, in particulary high doses of Dex, in glioma prognosis and patients survival suggests the existence of sialic acid-based mechanisms that regulate functional alterations in cancer immunosurveillance. 
Funding This work was funded by Grant from National Science Centre (N/NCN/MI/17/001/1166) and Grant from Medical University of Bialystok (N/ST/ZB/15/001/1166).

\section{Compliance with ethical standards}

Conflict of interest The authors declare that they have no conflict of interest.

Ethical approval This article does not contain any studies with human participants or animals performed by any of the authors.

Open Access This article is distributed under the terms of the Creative Commons Attribution 4.0 International License (http://creativeco mmons.org/licenses/by/4.0/), which permits unrestricted use, distribution, and reproduction in any medium, provided you give appropriate credit to the original author(s) and the source, provide a link to the Creative Commons license, and indicate if changes were made.

\section{References}

1. Batash R, Asna N, Schaffer P, Francis N, Schaffer M (2017) Glioblastoma multiforme, diagnosis and treatment; recent literature review. Curr Med Chem 24:3002-3009. https://doi. org/10.2174/0929867324666170516123206

2. Qazi MA, Vora P, Venugopal C, Sidhu SS, Moffat J, Swanton C, Singh SK (2017) Intratumoral heterogeneity: pathways to treatment resistance and relapse in human glioblastoma. Ann Oncol 28:1448-1456. https://doi.org/10.1093/annonc/mdx169

3. Heiland DH, Ferrarese R, Claus R, Dai F, Masilamani AP, Kling E, Weyerbrock A, Kling T, Nelander S, Carro MS (2017) c-JunN-terminal phosphorylation regulates DNMT1 expression and genome wide methylation in gliomas. Oncotarget 8:6940-6954. https://doi.org/10.18632/oncotarget.14330

4. Mondal B, Patil V, Shwetha SD, Sravani K, Hegde AS, Arivazhagan A, Santosh V, Kanduri M, Somasundaram K (2017) Integrative functional genomic analysis identifies epigenetically regulated fibromodulin as an essential gene for glioma cell migration. Oncogene 36:71-83. https://doi.org/10.1038/onc.2016.176

5. Djuzenova CS, Fiedler V, Memmel S, Katzer A, Hartmann S, Krohne G, Zimmermann H, Scholz CJ, Polat B, Flentje M, Sukhorukov VL (2015) Actin cytoskeleton organization, cell surface modification and invasion rate of 5 glioblastoma cell lines differing in PTEN and p53 status. Exp Cell Res 330:346-357. https:// doi.org/10.1016/j.yexcr.2014.08.013

6. Collins VP (2004) Brain tumours: classification and genes. J Neurol Neurosurg Psychiatry 75:ii2-i11

7. Oh T, Fakurnejad S, Sayegh ET, Clark AJ, Ivan ME, Sun MZ, Safaee M, Bloch O, James CD, Parsa AT (2014) Immunocompetent murine models for the study of glioblastoma immunotherapy. J Transl Med 29:107. https://doi.org/10.1186/1479-5876-12-107

8. Candolfi M, Curtin JF, Nichols WS, Muhammad AG, King GD, Pluhar GE, McNiel EA, Ohlfest JR, Freese AB, Moore PF, Lerner J, Lowenstein PR, Castro MG (2007) Intracranial glioblastoma models in preclinical neuro-oncology: neuropathological characterization and tumor progression. J Neurooncol 85:133-148. https ://doi.org/10.1007/s11060-007-9400-9

9. Adams OJ, Stanczak MA, von Gunten S, Läubli H (2017) Targeting sialic acid-Siglec interactions to reverse immune suppression in cancer. Glycobiology. https://doi.org/10.1093/glycob/cwx108
10. Silva M, Silva Z, Marques G, Ferro T, Gonçalves M, Monteiro M, van Vliet SJ, Mohr E, Lino AC, Fernandes AR, Lima FA, van Kooyk Y, Matos T, Tadokoro CE, Videira PA (2016) Sialic acid removal from dendritic cells improves antigen cross-presentation and boosts anti-tumor immune responses. Oncotarget 7:4105341066. https://doi.org/10.18632/oncotarget.9419

11. Pearce OM, Läubli H (2016) Sialic acids in cancer biology and immunity. Glycobiology 26:111-128. https://doi.org/10.1093/ glycob/cwv097

12. Kim YH, Min KH, Wang Z, Kim J, Jacobson O, Huang P, Zhu G, Liu Y, Yung B, Niu G, Chen X (2017) Development of sialic acid-coated nanoparticles for targeting cancer and efficient evasion of the immune system. Theranostics 7:962-973. https://doi. org/10.7150/thno.19061

13. Varki A (2008) Sialic acids in human health and disease. Trends Mol Med 14:351-360. https://doi.org/10.1016/j.molme d.2008.06.002

14. Ngampasutadol J, Ram S, Gulati S, Agarwal S, Li C, Visintin A, Monks B, Madico G, Rice PA (2008) Human factor H interacts selectively with Neisseria gonorrhoeae and results in speciesspecific complement evasion. J Immunol 180:3426-3435. https ://doi.org/10.4049/jimmunol.180.5.3426

15. Jandus C, Boligan KF, Chijioke O, Liu H, Dahlhaus M, Démoulins T, Schneider C, Wehrli M, Hunger RE, Baerlocher GM, Simon HU, Romero P, Münz C, von Gunten S (2014) Interactions between Siglec-7/9 receptors and ligands influence NK celldependent tumor immunosurveillance. J Clin Invest 124:1810 1820. https://doi.org/10.1172/JCI65899

16. Bhide GP, Colley KJ (2017) Sialylation of N-glycans: mechanism, cellular compartmentalization and function. Histochem Cell Biol 147:149-174. https://doi.org/10.1007/s00418-016-1520-x

17. Vojta A, Samaržija I, Bočkor L, Zoldoš V (2016) Glyco-genes change expression in cancer through aberrant methylation. Biochim Biophys Acta 1860:1776-1785. https://doi.org/10.1016/j. bbagen.2016.01.002

18. Vajaria BN, Patel KR, Begum R, Patel PS (2016) Sialylation: an avenue to target cancer cells. Pathol Oncol Res 22:443-447. https ://doi.org/10.1007/s12253-015-0033-6

19. Somplatzki S, Mühlenhoff M, Kröger A, Gerardy-Schahn R, Böldicke T (2017) Intrabodies against the polysialyltransferases ST8SiaII and ST8SiaIV inhibit polysialylation of NCAM in rhabdomyosarcoma tumor cells. BMC Biotechnol 17:42. https://doi. org/10.1186/s12896-017-0360-7

20. Szabo R, Skropeta D (2017) Advancement of sialyltransferase inhibitors: therapeutic challenges and opportunities. Med Res Rev 37:219-270. https://doi.org/10.1002/med.21407

21. Karhadkar TR, Pilling D, Cox N, Gomer RH (2017) Sialidase inhibitors attenuate pulmonary fibrosis in a mouse model. Sci Rep 7:15069. https://doi.org/10.1038/s41598-017-15198-8

22. Kostaras X, Cusano F, Kline GA, Roa W, Easaw J (2014) Use of dexamethasone in patients with high-grade glioma: a clinical practice guideline. Curr Oncol 21:493-503. https://doi.org/10.3747/ co.21.1769

23. Wong ET, Lok E, Gautam S, Swanson KD (2015) Dexamethasone exerts profound immunologic interference on treatment efficacy for recurrent glioblastoma. Br J Cancer 113:232-241. https://doi. org/10.1038/bjc.2015.404

24. Pitter KL, Tamagno I, Alikhanyan K, Hosni-Ahmed A, Pattwell SS, Donnola S, Dai C, Ozawa T, Chang M, Chan TA, Beal K, Bishop AJ, Barker CA, Jones TS, Hentschel B, Gorlia T, Schlegel U, Stupp R, Weller M, Holland EC, Hambardzumyan D (2016) Corticosteroids compromise survival in glioblastoma. Brain 139:1458-1471. https://doi.org/10.1093/brain/aww046

25. Shannon S, Vaca C, Jia D, Entersz I, Schaer A, Carcione J, Weaver M, Avidar Y, Pettit R, Nair M, Khan A, Foty RA (2015) Dexamethasone-mediated activation of fibronectin matrix assembly 
reduces dispersal of primary human glioblastoma cells. PLoS ONE 10:e0135951. https://doi.org/10.1371/journal.pone.0135951

26. Bavaresco L, Bernardi A, Braganhol E, Wink MR, Battastini AM (2007) Dexamethasone inhibits proliferation and stimulates ecto-5'-nucleotidase/CD73 activity in C6 rat glioma cell line. J Neurooncol 84:1-8. https://doi.org/10.1007/s11060-007-9342-2

27. Amoureux MC, Coulibaly B, Chinot O, Loundou A, Metellus P, Rougon G, Figarella-Branger D (2010) Polysialic acid neural cell adhesion molecule (PSA-NCAM) is an adverse prognosis factor in glioblastoma, and regulates olig2 expression in glioma cell lines. BMC Cancer 10:1-12. https://doi.org/10.1186/1471-2407-10-91

28. Schwab DE, Lepski G, Borchers C, Trautmann K, Paulsen F, Schittenhelm J (2018) Immunohistochemical comparative analysis of GFAP, MAP-2, NOGO-A, OLIG-2 and WT-1 expression in WHO 2016 classified neuroepithelial tumours and their prognostic value. Pathol Res Pract 214:15-24. https://doi.org/10.1016/j. prp.2017.12.009

29. Bradford MM (1976) A rapid and sensitive method for the quantitation of microgram quantities of protein utilizing the principle of protein-dye binding. Anal Biochem 72:248-254

30. Wu A, Wiesner S, Xiao J, Ericson K, Chen W, Hall WA, Low WC, Ohlfest JR (2007) Expression of MHC I and NK ligands on human CD 133+ glioma cells: possible targets of immunotherapy. J Neurooncol 83:121-131. https://doi.org/10.1007/s11060-006-9265-3

31. Zagzag D, Salnikow K, Chiriboga L, Yee H, Lan L, Ali MA, Garcia R, Demaria S, Newcomb EW (2005) Downregulation of major histocompatibility complex antigens in invading glioma cells: stealth invasion of the brain. Lab Invest 85:328-341. https ://doi.org/10.1038/labinvest.3700233

32. Newcomb EW, Lukyanov Y, Kawashima N, Alonso-Basanta M, Wang S, Liu M, Jure-Kunkel M, Zagzag D, Demaria S, Formenti SC (2010) Radiotherapy enhances antitumor effect of anti-CD137 therapy in a mouse glioma model. Radiat Res 173:426-432. https ://doi.org/10.1667/RR1904.1

33. Lu J, Gu J (2015) Significance of $\beta$-galactoside $\alpha 2,6$ sialyltranferase 1 in cancers. Molecules 20:7509-7527. https://doi. org/10.3390/molecules20057509

34. Cui HX, Wang H, Wang Y, Song J, Tian H, Xia C, Shen Y (2016) ST3Gal III modulates breast cancer cell adhesion and invasion by altering the expression of invasion-related molecules. Oncol Rep 36:3317-3324. https://doi.org/10.3892/or.2016.5180

35. Rodrigues E, Macauley MS (2018) Hypersialylation in cancer: modulation of inflammation and therapeutic opportunities. Cancers. https://doi.org/10.3390/cancers 10060207

36. Dai D, Nanthakumar NN, Savidge TC, Newburg DS, Walker WA (2002) Region-specific ontogeny of alpha-2,6-sialyltransferase during normal and cortisone-induced maturation in mouse intestine. Am J Physiol Gastrointest Liver Physiol 282:G480-G490. https://doi.org/10.1152/ajpgi.00531.2000

37. Coughlan CM, Seckl JR, Fox DJ, Unsworth R, Breen KC (1996) Tissue-specific regulation of sialyltransferase activities in the rat by corticosteroids in vivo. Glycobiology $6: 15-22$

38. Flowers HM, Sharon N (1979) Glycosidases-properties and application to the study of complex carbohydrates and cell surfaces. Adv Enzymol Relat Areas Mol Biol 48:29-95

39. Glick MC, Comstock C, Warren L (1970) Membranes of animal cells. VII. Carbohydrates of surface membranes and whole cells. Biochim Biophys Acta 219:290-300

40. Pogge von Strandmann E, Reinartz S, Wager U, Müller R (2017) Tumor-host cell interactions in ovarian cancer: pathways to therapy failure. Trends Cancer 3:137-148. https://doi.org/10.1016/j. trecan.2016.12.005

41. De Sanctis F, Ugel S, Facciponte J, Facciabene A (2018) The dark side of tumor-associated endothelial cells. Semin Immunol 35:35-47. https://doi.org/10.1016/j.smim.2018.02.002
42. Fernandes JV, Cobucci RN, Jatobá CA, Fernandes TA, de Azevedo JW, de Araújo JM (2015) The role of the mediators of inflammation in cancer development. Pathol Oncol Res 21:527-534. https ://doi.org/10.1007/s12253-015-9913-z

43. Macauley MS, Crocker PR, Paulson JC (2014) Siglec-mediated regulation of immune function in disease. Nat Rev Immunol 14:653-666. https://doi.org/10.1038/nri3737

44. Crocker PR, Paulson JC, Varki A (2007) Siglecs and their role in immune system. Nat Rev Immunol 7:255-266. https://doi. org/10.1038/nri2056

45. Curran CS, Bertics PJ (2012) Eosinophils in glioblastoma biology. J Neuroinflamm 9:11. https://doi.org/10.1186/1742-2094-9-11

46. Massara M, Persico P, Bonavita O, Poeta VM, Locati M, Simonelli M, Bonecchi R (2017) Neutrophils in gliomas. Front Immunol 8:1349. https://doi.org/10.3389/fimmu.2017.01349

47. Pillai S, Netravali IA, Cariappa A, Mattoo H (2012) Siglecs and immune regulation. Annu Rev Immunol 30:357-392. https://doi. org/10.1146/annurev-immunol-020711-075018

48. Kiwamoto T, Katoh T, Tiemeyer M, Bochner BS (2013) The role of lung epithelial ligands for Siglec-8 and Siglec-F in eosinophilic inflammation. Curr Opin Allergy Clin Immunol 13:106-111. https ://doi.org/10.1097/ACI.0b013e32835b594a

49. Guo JP, Brummet ME, Myers AC, Na HJ, Rowland E, Schnaar RL, Zheng T, Zhu Z, Bochner BS (2011) Characterization of expression of glycan ligands for Siglec-F in normal mouse lungs. Am J Respir Cell Mol Biol 44:238-243. https://doi.org/10.1165/ rcmb.2010-0007OC

50. Tateno H, Crocker PR, Paulson JC (2005) Mouse Siglec-F and human Siglec- 8 are functionally convergent paralogs that are selectively expressed on eosinophils and recognize 6'-sulfo-sialyl Lewis $\mathrm{X}$ as a preferred glycan ligand. Glycobiology 15:11251135. https://doi.org/10.1093/glycob/cwi097

51. Uchimura K, Muramatsu H, Kaname T, Ogawa H, Yamakawa T, Fan QW, Mitsuoka C, Kannagi R, Habuchi O, Yokoyama I, Yamamura K, Ozaki T, Nakagawara A, Kadomatsu K, Muramatsu T (1998) Human $N$-acetylglucosamine-6- $O$-sulfotransferase involved in the biosynthesis of 6-sulfo sialyl Lewis X: molecular cloning, chromosomal mapping, and expression in various organs and tumor cells. J Biochem 124:670-678

52. Izawa M, Kumamoto K, Mitsuoka C, Kanamori C, Kanamori A, Ohmori K, Ishida H, Nakamura S, Kurata-Miura K, Sasaki K, Nishi T, Kannagi R (2000) Expression of sialyl 6-sulfo Lewis X is inversely correlated with conventional sialyl Lewis X expression in human colorectal cancer. Cancer Res 60:1410-1446

53. Kiwamoto T, Kawasaki N, Paulson JC, Bochner BS (2012) Siglec-8 as a drugable target to treat eosinophil and mast cellassociated conditions. Pharmacol Ther 135:327-336. https://doi. org/10.1016/j.pharmthera.2012.06.005

54. Engblom C, Pfirschke C, Zilionis R, Da Silva Martins J, Bos SA, Courties G, Rickelt S, Severe N, Baryawno N, Faget J, Savova V, Zemmour D, Kline J, Siwicki M, Garris C, Pucci F, Liao HW, Lin YJ, Newton A, Yaghi OK, Iwamoto Y, Tricot B, Wojtkiewicz GR, Nahrendorf M, Cortez-Retamozo V, Meylan E, Hynes RO, Demay M, Klein A, Bredella MA, Scadden DT, Weissleder R, Pittet MJ (2017) Osteoblasts remotely supply lung tumors with cancer-promoting SiglecF $F_{\text {high }}$ neutrophils. Science 358:eaal5081. https://doi.org/10.1126/science.aal5081

55. Moebius JM, Widera D, Schmitz J, Kaltschmidt C, Piechaczek C (2007) Impact of polysialylated CD56 on natural killer cell cytotoxicity. BMC Immunol 8:13. https://doi. org/10.1186/1471-2172-8-13

56. Zeng Z, Li M, Wang M, Wu X, Li Q, Ning Q, Zhao J, Xu Y, Xie J (2017) Increased expression of Siglec-9 in chronic obstructive pulmonary disease. Sci Rep 7:10116. https://doi.org/10.1038/ s41598-017-09120-5 
57. Wielgat P, Mroz RM, Stasiak-Barmuta A, Szepiel P, Chyczewska E, Braszko JJ, Holownia A (2015) Inhaled corticosteroids increase siglec-5/14 expression in sputum cells of COPD patients. Adv Exp Med Biol 839:1-5. https://doi.org/10.1007/5584_2014_51

58. Luedi MM, Singh SK, Mosley JC, Hatami M, Gumin J, Sulman EP, Lang FF, Stueber F, Zinn PO, Colen RR (2017) A
Dexamethasone-regulated Gene Signature Is Prognostic for Poor Survival in Glioblastoma Patients. J Neurosurg Anesthesiol 29:46-58. https://doi.org/10.1097/ANA.0000000000000368 